\title{
Prireditveni turizem
}

\author{
Marijana Sikošek \\ uP Fakulteta za turistične študije - Turistica \\ marijana.sikosek@fts.upr.si
}

\section{Uvod}

Prireditve pogosto predstavljajo motiv za potovanje in priložnost za udeležbo pri edinstvenih doživetjih, ki jih predstavlja vsebina oz. program prireditve, s tem pa tudi priložnost za obisk destinacije, na kateri se te odvijajo na prav poseben način. Pogosto so razumljene kot izrazno sredstvo njihovih protagonistov, kot dejavnik oblikovanja podobe kraja, kjer potekajo, in kot pritegovalni dejavnik obiska destinacije. Prav v slednjem predstavljajo stično točko z oblikovanjem turistične ponudbe na destinaciji in motiv za njen turistični obisk.

$\mathrm{V}$ prispevku se bomo osredotočili na pomen prireditev in na tipe prireditev glede na njihove posebnosti, lastnosti, ki jih imajo prireditve na destinaciji, predvsem pa njihovo vlogo, ki jo imajo v turizmu in pri oblikovanju potovalnih motivov, s tem pa tudi na pojav posebne, tematske oblike turizma, ki jo imenujemo prireditveni turizem. Zanj Getz (2008) poudarja, da deluje kot vezni člen med upravljanjem s prireditvami ter upravljanjem in marketingom destinacije. Pomena prireditev so se upravljalci začeli zavedati v 80. letih prejšnjega stoletja zaradi zavedanja in prepoznavanja njihovih (predvsem) pozitivnih učinkov, ki so jih izkazovale na destina-

Lesjak, M., Sikošek, M., in Kerma, S. (ur.). (2020). Tematski turizem: teoretični in aplikativni primeri oblik turizma $v$ svetu in Sloveniji. 
ciji (Mair in Witford, 2013). Pomembnejši med njimi so poleg oblikovanja potovalnih motivov zagotovo tudi oblikovanje imidža destinacije, vpliv na konkurenčnost destinacije in premagovanje sezonskih vplivov (desezonalicija) (Getz, 2008; Lucia, 2013; Connell idr., 2015). Lokalne oblasti in destinacijske organizacije vlagajo veliko naporov $\mathrm{v}$ podporo in popularizacijo prireditev prav zato, ker v njih vidijo pomembno strateško orodje za ekonomski razvoj, marketing destinacije in oblikovanje nacionalne identitete (Allen idr., 2011). Vendar pa se je kmalu po prelomu tisočletja prireditvam posvečalo več pozornosti tudi zaradi zavedanja, da predstavljajo pomemben člen pri oblikovanju kulture in umetnosti, urbanega razvoja, izobraževanja in turističnih potovanj (Bowdin idr., 2011). Vendar pa ob pozitivnih ne gre prezreti negativnih vplivov, ki jih imajo lahko prireditve na destinaciji (Sikošek, 2010), zato je naloga tako organizatorjev prireditev kot načrtovalcev razvojnih politik v segmentu prireditev, da jih znajo identificirati in predvideti ustrezne rešitve.

\section{Prireditve in pomen prireditvene dejavnosti}

Prireditve kot načrtovana in organizirana dejavnost predstavljanja različnih tematik oz. vsebin se v človeški zgodovini pojavljajo vse od antičnih časov dalje, ko so se prvič začele odvijati organizirane (športne) igre (Raj idr., 2013). Zagotovo pa prireditve človeka spremljajo od prazgodovine dalje, ko je s posebnimi obredi, rituali in praznovanji želel obeležiti pomembnejše mejnike v svojem življenju (Sikošek, 2010), kar počne še danes. Obisk prireditev že vse od njihovih začetkov v antičnih časih predstavlja ključno aktivnost v prostem času posameznikov. Kot poudarjajo Richards idr. (2013), pa je povečevanje prostega časa in prihodka privedlo do povečevanja obiska na prireditvah, s tem pa do povečevanja pomena prireditev na sploh. V moderni družbi sta se zato povečali ekonomska in družbena vloga prireditev, ki postajajo vse kompleksnejše po svoji vsebini in organizaciji, zato pomembno narašča tudi število udeležencev (Ferdinand in Shaw, 2012). Prireditve navsezadnje ne pomenijo le fizičnega povezovanja ljudi, temveč hkrati s tem tudi povezovanje njihovih idej, česar drugi komunikacijski mediji pogosto ne zmorejo (Allen idr., 2011). Človek z udeležbo na prireditvi torej zadovoljuje svoje fizične in socialne potrebe, vendar je težnja po zadovoljitvi slednjih močnejša (Getz, 2008). Udeležba na prireditvi predstavlja priložnost za umik iz vsakodnevne rutine, hkrati pa v času hitrega razvoja moder- 
nih tehnologij, ki nas siromaši socialnih interakcij, ljudje čutimo vse večjo potrebo po fizičnem povezovanju.

Prav družbena vloga različnih vrst prireditev je vzpodbudila raziskovanje na področju prireditev in njihove vloge v turizmu od poznih 70. let prejšnjega stoletja dalje; ta se je od 8o. let dalje stopnjevala (Getz in Page, 2016). Med prvimi je bila v 8o. letih pripoznana vloga prireditev kot kreatorja ugleda destinacij in marketinškega orodja destinacij, orodja konkurenčnosti destinacij (Getz, 2008). Prav tako je v literaturi zaslediti pomen prireditev pri desezonalizaciji ponudbe in povpraševanja (Connell idr., 2015; Getz in Page, 2016) ter njihovo vlogo pri ekonomskem razvoju, turističnem marketingu in razvoju, in sicer zaradi sposobnosti prireditev, da povečajo število turistov na destinaciji, oblikujejo pozitiven imidž destinacije in prispevajo $\mathrm{k}$ razvoju kraja, na drugi strani pa ustvarjajo nova delovna mesta in poslovne priložnosti (Ferdinand in Shaw, 2012). Čeprav je v literaturi pri zgodnjem raziskovanju mogoče opaziti predvsem izpostavljanje pozitivnih strani prireditev in s tem povezanih dejavnosti, je potrebno poudariti, da Getz in Page (2016) opozarjata, da se je prvo raziskovanje pomena prireditev začelo drugače. Avtorja izpostavljata, da so bile $\mathrm{v} 60$. in 7o. letih npr. prve objave usmerjene v razpravo o negativnih straneh ublagovljenja festivalov in umetniških prireditev za turistične potrebe; slednje je bilo namreč razumljeno predvsem kot negativen vpliv na njihovo avtentičnost.

Pri opredelitvi izraza prireditev ni enotne definicije. Med prvimi je prireditev kot fenomen zbiranja ljudi zaradi določene tematike opredelil Getz (1997; 2007). Zaradi ločevanja med izrazom »event « kot dogodkom, ki se lahko zgodi sam po sebi, in vnaprej organiziranim dogodkom, je uvedel izraz »special event«, kar lahko zato razumemo kot posebno prireditev, prirejeno za poseben namen in z vnaprej znanim naročnikom. Definiral jo je z dveh zornih kotov: s stališča organizatorja je "posebna prireditev enkratna ali redka, izven običajnega programa ali aktivnosti naročnika oz. plačnika«, s stališča udeleženca prireditve pa pomeni "možnost za prostočasno, družabno ali kulturno doživetje izven običajnega izbora oz. izven vsakodnevnih doživetij« (Getz, 1997, str. 4 v Sikošek, 2010). Vendar pa je v sodobnejši literaturi uporaba izraza special event postala manj pogosta in jo je nadomestil izraz event ali planned event, kot izraz, ki opredeljuje vnaprej načrtovano in organizirano prireditev (Getz, 2007; Mair in Whitford, 2013; Getz in Page, 2016). 
Tudi v slovenskem jeziku vlada na področju opredeljevanja izraza prireditev določena dvojnost oz. nedorečenost, na kar smo opozorili med prvimi (Sikošek, 2010). V slovenski terminologiji je v splošni rabi tako v praksi kot literaturi moč zaslediti dva izraza: prireditev in dogodek. Menimo, da je ustreznejša raba termina prireditev, kar nam dokazujejo tudi zapisi v Slovarju slovenskega knjižnega jezika (2014).

V Slovarju slovenskega knjižnega jezika (2014) je prireditev opredeljena kot »javni dogodek, zlasti kulturni, športni, zabavni« in opisana s primeri: »udeležiti se prireditve; odpovedati prireditev; nastopiti na prireditvi; dobrodelna prireditev; družabna prireditev; kulturna, pevska, športna prireditev; obisk prireditve; program prireditve; vstopnice za prireditev; knjižni sejem in druge prireditve«. Z njim se povezuje glagol prirediti, ki pomeni med drugim (glagol ima več pomenov) "narediti, kar je potrebno, da se kak javni dogodek začne, uresniči«, ko npr. "prirediti dirke, izlet, koncert, proslavo, zborovanje«.

Prav nasprotno pa izraz »dogodek« po slovarju (Slovar slovenskega knjižnega jezika, 2019) pomeni nekaj, »kar se zgodi«, npr. »dogodki so se vrstili z veliko naglico; težko je slediti vsem dogodkom; neprimeren, zanimiv dogodek«, v ekspresivni rabi pa tudi "posebno, nenavadno doživetje«, kot npr. »njegov nastop je bil vselej dogodek«.

Sklepamo lahko, da je zato primernejša raba izraza "prireditev«, kar dokazuje tudi pomen in raba pridevnika "prireditven«, ki po slovarju (Slovar slovenskega knjižnega jezika, 2019) označuje pojme, ki se nanašajo na prireditev: "nanašajoč se na prireditev: prireditveni program/prireditveni odbor; urediti prireditveni prostor; prireditvena poslovalnica, prireditveni prostor «. Obenem velja poudariti, da je uporaba izraza omenjena v Zakonu o javnih zbiranjih (zJzUPB5) (2011), kjer za javno prireditev velja vsako »organizirano zbiranje oseb zaradi izvajanja kulturne, športne, zabavne, izobraževalne, verske ali druge aktivnosti«.

Rabo izraza "prireditev« nakazujeta tudi literatura in razumevanje prireditvene dejavnosti kot organizirane dejavnosti, ki je splet različnih aktivnosti za dosego cilja - to je izvedbe prireditve. Vendar pa sta izraza medsebojno povezana. Dogodek lahko razumemo kot statično, prireditev pa kot dinamično kategorijo. Statičnost dogodka izhaja iz narave dogodka, ki se kaže v tem, da je dogodek povod za organizacijo prireditve in zato njen sestavni del. Prireditev pa je dinamična kategorija zato, ker zahteva vrsto organizacijskih aktivnos- 
ti, ki statični dogodek spremenijo v aktivno kategorijo - prireditev. Ta je zato običajno seštevek več dogodkov oz. vsebin v prireditvi, ki si v času trajanja prireditve sledijo druga za drugo ali potekajo vzporedno. Prireditev je zato edinstvena, vnaprej zamišljena, načrtovana, organizirana in skrbno izpeljana aktivnost, sestavljena iz niza posameznih dogodkov (Sikošek, 2010).

Podobne opredelitve je opaziti tudi pri drugih avtorjih. Shone in Parry (2004) trdita, da je prireditev nerutinska priložnost, ki ima prostočasne, kulturne, osebne ali organizacijske cilje, ki so ločeni od vsakdanjih aktivnosti, katerih namen je poudariti doživetje. Tudi Bladen idr. (2012) jo definirajo kot začasno zbiranje ljudi z določenim namenom, ki ima naslednje značilnosti: je začasna, pomeni zbiranje ljudi, pomeni določen obred in je v nekem pomenu poseben dogodek.

\section{Vrste prireditev}

Ko govorimo o motivih za udeležbo na prireditvah in s tem obisk destinacije, ne moremo mimo različnih vrst prireditev. V literaturi so jih avtorji opredeljevali in razlikovali po različnih kriterijih (Getz, 1997; Jago in Shaw, 1998; Shone in Parry, 2004; Getz, 2008; Raj idr., 2013), pri čemer je opaziti tudi različnost opredeljevanja skozi čas. V zgodnejših delih v 70. in 8o. letih prejšnjega stoletja (Getz, 1997) se je prireditve razvrščalo glede na kriterij trajanja, in sicer na dlje in manj časa trajajoče prireditve (angl. short-term, long-term events), oz. glede na kriterij velikosti na manjše, večje in velike prireditve (angl. small, mega, hallmark). Prav kriterij velikosti so avtorji v go. letih dopolnili tako, da so prireditve opredeljevali glede na velikost in njihov obseg kot manjše, večje, zelo velike (angl. major, mega, hallmark events) (Getz, 1997; 2007) oz. kot lokalne, regionalne, nacionalne, mednarodne in globalne (Bladen idr., 2012).

Prireditve lahko torej razvrstimo po različnih kriterijih, saj je, kot pravi Getz (2007), svet prireditev tako zelo širok, da je vsakršna razvrstitev že v začetku obsojena na nepopolnost. V literaturi sta najpogosteje omenjeni dve klasifikaciji Donalda Getza. Prva je delitev prireditev glede na obseg (velikost) in frekvenco ponavljanja, in sicer na lokalne, regionalne, periodične velike in občasne zelo velike prireditve, kar je avtor (2005) poimenoval kot "portfolio pristop« $\mathrm{k}$ vrednotenju prireditev. Druga klasifikacija je delitev glede na njihovo vsebino, pri čemer jih je avtor (1997) prvič razvrstil na javne in zaseb- 
Preglednica 6.1 Tipologija načrtovanih prireditev

\begin{tabular}{ll}
\hline Vrsta prireditev & Primeri \\
\hline Kulturne prireditve, proslave & $\begin{array}{l}\text { Festivali, karnevali, komemoracije, } \\
\text { religiozne prireditve. }\end{array}$ \\
\hline Poslovne in prodajne prireditve & $\begin{array}{l}\text { Poslovna srečanja in kongresi, prodajna } \\
\text { srečanja, sejmi in razstave. }\end{array}$ \\
\hline Športno-tekmovalne prireditve & $\begin{array}{l}\text { Za amaterske/profesionalne športnike, } \\
\text { za gledalce. }\end{array}$ \\
\hline Umetniške in zabavne prireditve & Koncerti, podelitve nagrad. \\
\hline Politične in državne prireditve & $\begin{array}{l}\text { Konference/kongresi, politična srečanja, } \\
\text { kraljevski dogodki, obiski državnikov. }\end{array}$ \\
\hline Izobraževalne in znanstvene prireditve & Konference, simpoziji, seminarji. \\
\hline Športno rekreativne prireditve & Športne prireditve, igre za zabavo. \\
\hline Zasebne prireditve & Poroke, zabave, družabna srečanja. \\
\hline Opombe Prirejeno po Getz (2005). &
\end{tabular}

ne, kasneje (2005) pa je to klasifikacijo dopolnil in jo sedaj poznamo kot tipologijo planiranih prireditev.

Razumevanje tipologije planiranih prireditev (preglednica 6.1) temelji na dejstvu, da gre za prireditve, ki so vnaprej načrtovane, torej ne nastanejo spontano. Med seboj se razlikujejo po vsebini, čeprav je možno prekrivanje posameznih vrst (Getz, 2005).

Getz in Page (2016) sta ponudila še drugačno tipologijo načrtovanih prireditev, razdeljenih na štiri glavne skupine (slika 6.1). Pri tej razvrstitvi gre za nekoliko kompleksnejše razumevanje prireditev ne zgolj z vsebinskega, ampak tudi s prostorskega stališča, predvsem v luči razvoja destinacijskega managementa in prireditvenega turizma. Prireditve v novejšem času tako niso več prepuščene posameznim ljubiteljem in skupnostim, ampak so postale predmet profesionalnega pristopa, ta pa zahteva kompleksno načrtovanje in povezovanje z gostiteljskim prostorom oz. destinacijo, kar vodi v razvoj prireditvenega turizma. Ob razvrščanju prireditev v te štiri skupine velja opozoriti, da bi jih lahko glede na vsebino, predvsem pa motiv obiska ločili na tiste, ki za obisk zahtevajo koriščenje posameznikovega prostega časa, in na tiste, kjer se udeležba pričakuje v času opravljanja službenih ali izobraževalnih obveznosti. Razdelili bi jih lahko torej na prostočasne in poslovne, pri čemer bi med prostočasne šteli zabavne in športne prireditve ter festivale in kulturne prireditve, poslovne prireditve pa so samostojna kategorija (Sikošek, 2017). 


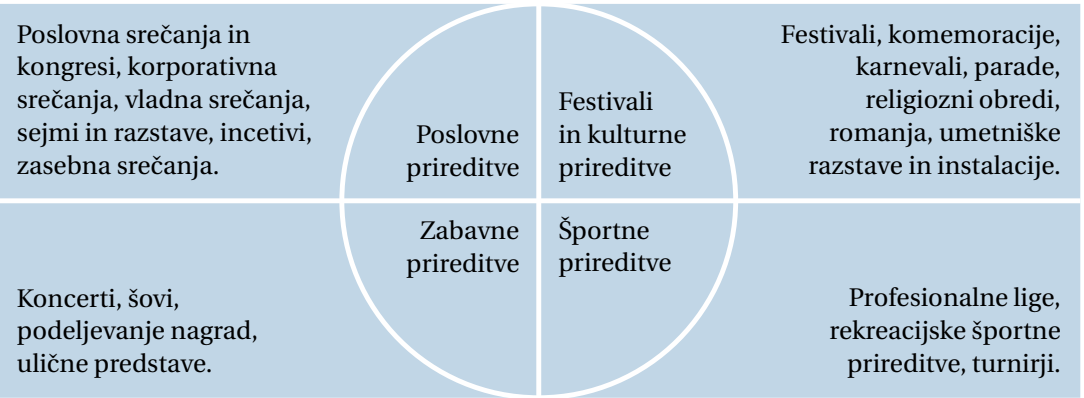

Slika 6.1 Razvrstitev prireditev po vsebini (prirejeno po Getz in Page, 2016)

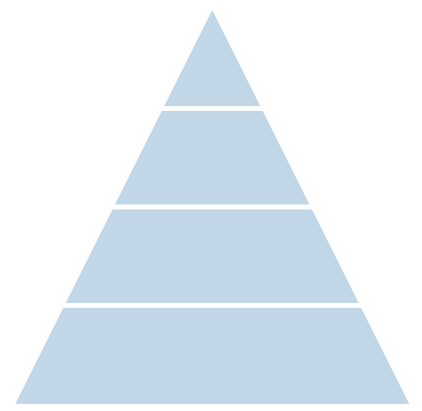

Občasne mega prireditve:
visoko turistično povpraševanje ali vrednost
Periodične hallmark prireditve:
visoko turistično povpraševanje ali vrednost
Regionalne prireditve (periodične in enkratne):
srednje visoko turistično povpraševanje ali vrednost
Lokalne prireditve (periodične in enkratne):
nizko turistično povpraševanje ali vrednost

Slika 6.2 Razvrstitev prireditev po portfolio pristopu (prirejeno po Getz in Page, 2016)

Drugi pristop pri razvrščanju prireditev je t.i. portfolio pristop (slika 6.2), ki ga je Getz (2005) uvedel zaradi lažjega razumevanja velikosti prireditev, njihove frekvence pojavljanja in samega vrednotenja, predvsem v luči prepoznavnosti, učinkov in zapuščine, ki jo lahko ima prireditev.

Ta pristop se je v literaturi tudi najbolj uveljavil, čeprav se prireditve po velikosti pogosto razvršča tudi glede na število udeležencev, in sicer na manjše, večje in zelo velike (Getz, 1997; 2007). Pri portfolio pristopu gre poleg velikosti oz. obsega same prireditve tudi za razumevanje, kakšen obseg turističnega povpraševanja lahko na destinaciji ustvari posamezna prireditev glede na svojo privlačnost in kakšno vrednost je sposobna ustvariti. Pri tem termin »vrednost« razumemo kot skupek (porftfolio) več kategorij, kot so potencial prireditve za prihodnjo rast, tržni delež prireditve, kakovost prireditve, večanje ugleda prireditve in destinacije, podpora skupnosti, izboljšanje okolja, trajnost, primernost prireditve, medijska pozor- 
nost (Getz, 2005). Prireditev lahko ustvari samo eno vrednostno kategorijo (npr. kakovost prireditve), vendar pa gre v praksi običajno za ustvarjanje več kategorij (npr. kakovost prireditve, večanje ugleda prireditve in podpora lokalne skupnosti). Kot poudarjata Getz in Page (2016), je portfolio prireditve oz. skupek vrednosti tudi merilo za strateško načrtovanje razvoja prireditev na destinaciji: prav ocena vrednosti, ki jo prireditev lahko ustvari, je element, na podlagi katerega se lahko načrtovalci razvojnih politik odločijo, ali bodo podprli določeno prireditev ali ne in koliko ter kakšne vrste prireditev bodo $\mathrm{v}$ prihodnje razvijali. V praksi se takšna podpora kaže v različnih dejanjih: od medijske do infrastrukturne podpore prireditvi pa vse do podpore in sodelovanja gostiteljske destinacije pri pripravi kandidature za organizacijo prireditve. Rezultat portfolio pristopa pri destinacijskem načrtovanju prireditev je uravnotežen nabor manjših in večjih prireditev z različnimi vsebinami in učinki. Še posebej večje prireditve so tiste, ki za destinacijo lahko pomenijo možnost novih vlaganj, zaposlitev in izboljšanje družbeno-ekonomskega položaja.

Po portfolio pristopu med manjše prireditve uvrščamo lokalne in regionalne prireditve. Najmanjše prireditve so tiste, ki so bolj lokalnega značaja in ustvarijo manjše turistično povpraševanje ter vrednost. Te prireditve so lahko po frekvenci prirejanja periodične (se ponavljajo) ali enkratne. Primer za takšne prireditve so vse lokalne prireditve, na primer prireditev Vonj po Istri v Krkavčah (https://www.vonjpoistri.krkavce.si). Med regionalne prireditve sodijo tiste, ki ustvarijo nekoliko večje turistično povpraševanje in vrednost ter so prav tako lahko periodične ali enkratne. Kot primer za takšno prireditev lahko navedemo periodično športno prireditev Istrski maraton (https://www.istrski-maraton.si), ki med seboj povezuje več regij, privabi relativno večje število udeležencev in generira turistično povpraševanje ter vrednost, ki je običajno sestavljena iz skupka več kategorij. Prireditev je prav zato deležna podpore lokalne skupnosti in gospodarstva, v zameno pa je za destinacijo ustvarila kar nekaj vrednosti, kot so prepoznavnost med tekaškimi prireditvami, dvig imidža destinacije, povečan obisk destinacije izven turistične sezone. Getz in Page (2016) poudarjata, da je potrebno vrednost lokalnih in regionalnih prireditev razumeti s previdnostjo, saj nekatere med njimi nikoli ne razvijejo turističnega potenciala, ker si tega niti ne želijo ali pa za to nimajo možnosti. Kot primer navajata manjše kulturne prireditve v lokalnih skupnostih, ki so namenjene le do- 
mačinom in nimajo nobenega namena privabiti turistov, ali pa božične sejme, ki so prvenstveno namenjeni domačinom, vendar pa so (nekateri) sčasoma zaradi vse večjega obiska turistov razvili velik turistični potencial. Vsekakor pa je tako lokalne kot regionalne prireditve treba razumeti kot tiste, ki so neločljivo povezane, lahko bi rekli zraščene, $\mathrm{z}$ destinacijo, na kateri potekajo in so v prvi vrsti namenjene lokalni skupnosti.

Med večje prireditve po portfolio pristopu prištevamo t.i. »hallmark prireditve« in »megaprireditve«. To so prireditve, ki so sposobne ustvariti zelo veliko turistično povpraševanje in vrednost. Prireditve tipa hallmark so tiste, ki imajo lahko več pomenov. $Z$ njihovo opredelitvijo se je prvi ukvarjal Ritchie leta 1984 (v Getz in Page, 2016, str. 598), ki jih je definiral kot "velike enkratne ali ponavljajoče se prireditve $\mathrm{z}$ določenim trajanjem, ustvarjene $\mathrm{z}$ namenom poudariti prepoznavnost in donosnost turističnih destinacij«, pri čemer so to lahko športne, kulturne, verske, politične prireditve ali festivali. Getz (2005, str. 598-599) je za hallmark prireditve označil tiste, ki imajo prav poseben pomen v smislu tradicije, atraktivnosti, kakovosti ali medijske prepoznavnosti, saj gostiteljski destinaciji priskrbijo posebno konkurenčno prednost. Kot ugotavljata Getz in Page (2016) je značilna lastnost teh prireditev njihova prav posebna povezanost ali tudi odvisnost vsebine prireditve $\mathrm{z}$ značilnostmi gostiteljske destinacije. Kot primer takšne prireditve navajata Mardi Gras, ki je značilna prireditev za mesto New Orleans. Prireditev tipa hallmark lahko torej razumemo kot tradicionalno, ponavljajočo se prireditev, ki destinaciji pusti poseben pečat, ki postane njen zaščitni znak.

Med »megaprireditve« po portfolio pristopu prištevamo občasne prireditve, ki imajo sposobnost pritegniti zelo veliko turistično povpraševanje in vrednost za destinacijo. Veljajo za največje prireditve, ki jih je mogoče organizirati. Najsplošnejši primer takšne prireditve so olimpijske igre, Svetovno prvenstvo v nogometu, Expo (Getz in Page, 2016). Merila za označitev velikosti megaprireditev so bila prvič določena leta 1987 na kongresu AIEST (Association Internationale D'Experts Scientifiques Du Tourisme), najstarejšega združenja strokovnjakov na področju turizma. Velikostne kategorije so bile ob določitvi naslednje: obseg udeležencev (1 milijon), denarna vrednost (50o milijonov kanadskih dolarjev) in psihološka vrednost, merjena z ugledom prireditve, ki ga izraža besedna zveza must see. Definicija oz. razumevanje megaprireditev se je sčasoma noveliralo, v novej- 
šem času gre predvsem za razumevanje, da so to občasne in zelo velike prireditve, ki so zlasti globalno usmerjene in vsebinsko niso nujno povezane $\mathrm{z}$ destinacijo, na kateri se odvijajo. Za megaprireditve je zato značilen predvsem proces kandidature, v katerem sodelujejo potencialne gostiteljske destinacije $\mathrm{z}$ namenom oblikovanja prepoznavnosti in imidža destinacije, to je države, posameznih krajev in specializiranih prizorišč (Lai, 2015). Müller (2015) ugotavlja, da so megaprireditve enoten pojem za res zelo velike prireditve, ki so po svoji velikosti precej večje kot običajne prireditve in imajo točno določeno trajanje. Pri tem poudarja, da jih določajo štiri ključne dimenzije:

- število obiskovalcev: običajno več kot milijon, lahko tudi več kot deset milijonov obiskovalcev, merjenih v povprečnem številu prodanih vstopnic;

- medijska privlačnost oz. medijski doseg: merjeno v finančnem obsegu prodanih pravic za prenos prireditve preko določenega medija;

- višina stroškov za organizacijo in izvedbo: običajno več kot ena milijarda usD, lahko tudi več deset;

- obseg urbane transformacije: merjeno v stroških za naložbe, namenjene za izgradnjo ustrezne infrastrukture za izvedbo megaprireditve.

Müller (2015) ugotavlja tudi, da se ta vrsta prireditev v svoji velikosti med seboj razlikuje, zato obenem glede na štiri zgornje dimenzije predlaga drugačno razvrstitev zelo velikih prireditev, in sicer na »major-«, »mega-« in "gigaprireditve«. Kot primer za majorprireditev navaja npr. APEc Summit leta 2012 v Vladivostoku, kot primer gigaprireditve pa olimpijske igre v Londonu leta 2012.

Razvrščanje prireditev glede na velikost zaposluje mnoge raziskovalce in tudi praktike vse od začetkov pojavljanja modernih prireditev, to je od začetka 8o. let prejšnjega stoletja. Tako kot na eni strani Müller (2015) predlaga še dodatno klasifikacijo zelo velikih prireditev, ki imajo predvsem globalen pomen, in se sprašuje, kje je njihova razumna meja, se je Hall (1992) spraševal, kakšen pomen ima delitev prireditev po velikostnih kriterijih. Ugotavljal je namreč, da so mega- in hallmark prireditve resda velike zaradi svoje mednarodne prepoznavnosti, vendar pa so za skupnost, destinacijo ali državo hallmark prireditve lahko tudi manjše prireditve lokalnega ali regio- 
nalnega značaja, ki so torej prav tako velike in pomembne, saj jim dajejo prav poseben pečat in prepoznavnost.

\section{Prireditve v Sloveniji}

V Sloveniji poznamo veliko vrst prireditev, ki se med seboj razlikujejo tako po vsebini kot tudi velikosti. Zagotovo je Slovenija prepoznavna prireditvena destinacija tudi izven svojih meja, saj jo označuje kar nekaj mednarodno priznanih prireditev. Med njimi velja omeniti organizacijo ene izmed največjih športnih prireditev v Sloveniji, to je finale Svetovnega prvenstva v smučarskih skokih in finale Svetovnega pokala v smučarskih skokih v Planici. Med kulturnimi prireditvami je zagotovo ena večjih, ki ima izjemno dolgo tradicijo prirejanja, festivalska prireditev Festival Lent v Mariboru.

V Sloveniji sicer nimamo posebne kategorizacije prireditev, prav tako ne najdemo centralnega registra ali pa seznama prireditev, ki bi nam lahko ponudila pregled teh dogodkov v Sloveniji. Za leto 2019 je Slovenska turistična organizacija pripravila seznam večjih prireditev v Sloveniji (Slovenian Tourist Board, 2019), in sicer za potrebe promocije na tujih agencijskih trgih. Na seznamu je nanizala okoli 180 različnih vrst prireditev, in sicer zgolj prostočasne prireditve, medtem ko poslovnih prireditev ni. Naštete prireditve se med seboj razlikujejo tako po vsebini kot tudi velikosti. Tako so med njimi takšne, ki bi jih glede na velikostne kriterije razvrstili med zelo velike (planiški skoki, Festival Lent), ali takšne, ki so bolj regionalnega ali celo lokalnega značaja. Glede na vsebino je med njimi najti športne, kulturne in zabavne prireditve ter festivale.

$\mathrm{Na}$ uradni spletni strani Slovenske turistične organizacije (http://www.slovenia.info/sl/dozivetja/dogodki) so prireditve razvrščene po vsebinskem kriteriju na glasbene, športne, zabavne, gastronomske in otroške prireditve, ki bi jih lahko šteli med prostočasne prireditve, ter na sejme, gospodarske in promocijske razstave, ki bi jih lahko uvrstili med poslovne prireditve.

\section{Management prireditev}

Kot pravijo Allen idr. (2011) so prireditve aktivnosti, s katerimi ljudje obeležujemo, poudarjamo, praznujemo prav posebne dogodke oz. dosegamo prav posebne socialne, kulturne ali poslovne cilje. Da bi z njimi dosegli zastavljeni cilj, morajo biti skrbno organizirane in izvedene. Kot trdi M. Sikošek (2010) je management prireditev upravljal- 
ski proces, znotraj katerega se odvijajo določene dejavnosti za dosego cilja, to je izvedbe prireditve. Moderne prireditve, kot jih poznamo in obravnavamo od druge polovice prejšnjega stoletja dalje, so prireditve, pri katerih njihova organizacija in izvedba nista naključje, ampak z njimi upravljajo posebej usposobljeni posamezniki. Lahko trdimo, da se področje prireditev vse bolj profesionalizira, za kar so potrebna posebna znanja in veščine.

Management prireditev velja za samostojno organizacijsko dejavnost, ki sledi načelom splošnega managementa, zato jo sestavlja več upravljalskih in organizacijskih funkcij. Vse od prvih objav (Getz, 1997) do danes se management prireditev obravnava kot preplet funkcij raziskovanja, oblikovanja (programa in različnih aktivnosti), načrtovanja, koordiniranja in vrednotenja (Quinn, 2013), ki v zadnjih desetletjih vse bolj pridobiva na veljavi. Zagotovo gre razlog iskati v vse večji popularizaciji prireditev, ki so prerasle svoj prvotni namen in danes pomenijo ne le sredstvo za obeležitev pomembnejših dogodkov, ampak tudi sredstvo komuniciranja, priložnost za razvoj lokalnih skupnosti in destinacij v družbenem, ekonomskem, političnem in okoljskem pomenu. Tudi zaradi pomena, ki jih imajo prireditve, se k njihovemu upravljanju in organizaciji ne pristopa več ljubiteljsko, ampak profesionalno, prav profesionalizacija pa zaradi vloge, ki jo prireditev na destinaciji lahko ima, vodi v vse večji razvoj managementa prireditev, tako na raziskovalni kot strokovni ravni.

Prav profesionalizacija in razvoj managementa prireditev sta privedla do oblikovanja novih delovnih mest, kot so manager prireditve, vodja prireditve, producent prireditve, koordinator prireditve, analitik prireditev, raziskovalec prireditev, načrtovalec prireditve, tudi destinacijski manager prireditev in podobno. Prav razvoj in razmah prireditev vodita tudi do pojava vse več izobraževalnih programov s področja managementa prireditev (Getz, 2008; Allen idr., 2011; Getz in Page, 2016).

Ko govorimo o managementu oz. upravljanju posamezne prireditve, moramo pojasniti vlogo okolja prireditve. Prireditev namreč nastane zaradi upravljalsko-organizacijskih aktivnosti in v povezavi s svojim notranjim in zunanjim okoljem, kar predstavlja sistem povezanih in medsebojno odvisnih elementov. Getz (2007) o managementu prireditev govori kot o sistemu, ki je sestavljen iz osnovne celice - prireditve, iz katere se navzven širijo področja posameznega okolja. Ta področja so: notranje okolje, ki ga predstavlja upravljanje 


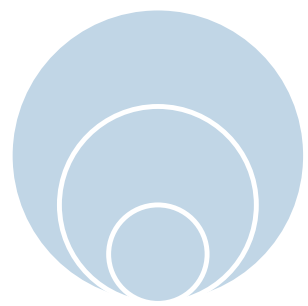

\section{Širše zunanje okolje: lokalna skupnost ter regionalno, nacionalno, nadnacionalno in globalno okolje \\ Ožje zunanje okolje: dobavitelji občina, upravna enota, turistična organizacija, lokalna skupnost, sponzorji \\ Notranje okolje: manager prireditve, prostovoljci, organizacijski team}

Slika 6.3 Management prireditev kot sistem in njegovo okolje (prirejeno po Getz, 2007, in Sikošek, 2010)

prireditve; ožje zunanje okolje, ki ga predstavljajo meje lokalne skupnosti, v kateri se prireditev odvija; in širše zunanje okolje, katerega velikost je odvisna od zunanje prepoznavnosti prireditve. Na sliki 6.3 je prikazan sistem kot splet povezanih elementov, ki delujejo v odvisnosti drug od drugega in hkrati vplivajo drug na drugega. Tako lahko vsaka sprememba v zunanjem okolju vpliva na notranje okolje prireditve, torej na njeno izvajanje in uspešnost; ravno tako pa lahko prireditev vpliva na zunanje okolje prireditve, to je na lokalno skupnost, ekonomsko, družbeno in naravno okolje. Iz tega razloga je potrebno $\mathrm{v}$ fazi načrtovanja zaznati morebitne medsebojne vplive in ovrednotiti njihove posledice.

\section{Prireditveni turizem in pojem turistične prireditve}

Čeprav se je pojem posebnih prireditev kot pojem, s katerim označujemo načrtovane prireditve za poseben namen in cilj, začel pojavljati ob koncu 7o. let prejšnjega stoletja, naj bi se izraz »prireditveni turizem« prvič pojavil šele leta 1987 v poročilu novozelandske turistične in marketinške organizacije. Ta je takrat ugotavljala, da »je prireditveni turizem pomemben in hitro rastoč segment mednarodnega turizma« (Getz in Page, 2016, str. 597). Dve leti pozneje je Getz (1989) kot prvi avtor objavil temeljna izhodišča za načrtovanje prireditvenega turizma, kjer se je zavzemal za interpretacijo, da so prireditve posebna oblika turističnega produkta, ki se jih ne more izkoristiti zgolj kot atrakcijo v načrtovanju turističnega razvoja, ampak kot poseben koncept, ki lahko prispeva k razvoju destinacij na svojstven način. Lahko trdimo, da povezava med prireditvami in turizmom ni nova, medtem ko se je razumevanje prireditev kot posebnega tematskega področja v turizmu začelo razvijati šele v poznih 8o. letih prejšnjega stoletja. Getz in Page (2016) poudarjata, da je treba pojem prireditve- 
ni turizem razumeti kot povezovalno sredstvo za vse planirane prireditve, ki kot take sestavljajo integrirani model za razvoj in trženje destinacij.

Getz je leta 1997 prvič opredelil prireditveni turizem kot poseben del tematskega turizma. Pri tem ga je definiral tako s strani ponudbe, to je gostiteljske destinacije, kot s strani povpraševanja, to je udeleženca oz. potrošnika prireditve.

S strani ponudbe oz. destinacije je prireditveni turizem potrebno razumeti kot premišljeno načrtovanje, razvoj in promocijo različnih vrst prireditev. Prireditve tako postanejo usmerjevalec nadaljnjega razvoja destinacije, tako turističnega kot družbeno-ekonomskega, in pripomorejo h krepitvi njenega ugleda ter delujejo kot pritegovalni element. Prireditveni turizem je tako treba razumeti kot posebno strateško področje v turizmu in kot orodje v trženju destinacij (Getz, 1997; Getz in Page, 2016).

Pri razumevanju prireditvenega turizma s strani povpraševanja oz. s perspektive potrošnika prireditve (udeleženca) je potrebno najprej odgovoriti na vprašanja, kdo in zakaj potuje zaradi obiska prireditve in kdo se udeležuje prireditve, medtem ko je na potovanju. S strani povpraševanja torej pomeni prireditveni turizem točno določeno skupino ljudi - turistov, ki bodisi potujejo izključno zato, da se udeležijo prireditve, bodisi se prireditve udeležijo takrat, ko bivajo izven kraja stalnega bivališča (Getz, 1997; Getz in Page, 2016).

Prav poznavanje posebnosti glede ponudbe in povpraševanja po prireditvah zahteva poznavanje vloge, ki jo imajo prireditve, s tem pa tudi prireditveni turizem pri razvoju destinacij. Getz in Page (2016, str. 597) prireditvam pripisujeta naslednje vloge:

- prireditve lahko privabijo turiste kot tudi sponzorje in medije, ki sicer ne bi obiskali destinacije, potrošnja obiskovalcev prireditve oz. prireditvenih turistov ustvarja ekonomske koristi, prireditveni turizem je lahko vzvod za premagovanje sezonskosti, orodje za geografsko širitev turizma ter za urbani in ekonomski razvoj, oblikovanje posebnega nabora - portofolia prireditev na destinaciji pa lahko prispeva k večjim učinkom in usmerjenosti $\mathrm{v}$ različne segmente obiskovalcev;

- prireditve lahko oblikujejo pozitiven imidž destinacije, prispevajo k oblikovanju ali krepitvi destinacijske znamke ali repozicioniranju kraja; 
- prireditve prispevajo $\mathrm{k}$ trženju mest ali krajev, saj so zaradi njih mesta privlačnejša;

- prireditve s svojo vsebino poskrbijo za animacijo in s tem za večjo privlačnost mest, turističnih kompleksov, parkov, urbanih prostorov in prizorišč različnih vrst za (ponovni) obisk in za njihovo učinkovitejšo rabo;

- prireditve delujejo kot katalizator razvoja v kraju oz. na destinaciji, kar se kaže v njegovi prenovi, vlaganju v razvoj infrastrukture, povečevanju zaposlitvenih možnosti za lokalno prebivalstvo.

Prireditve imajo torej več lastnosti, ki se kažejo na različne načine. Imajo sposobnost, da na destinacijo privabijo večje število udeležencev, kar se lahko kaže v povečanem številu ustvarjenih nočitev in podaljšani dobi bivanja. To ima za posledico povečevanje prihodkov tako na ravni destinacije (npr. iz naslova turistične takse) kot na ravni posamezne organizacije (npr. povečano trošenje gosta v nastanitvenih in prehrambenih objektih, trgovinah in podobno), še posebej so ti učinki pomembni v nesezoni. Prireditve imajo tudi sposobnost, da oživijo življenjski utrip na destinaciji, kar poveča zanimanje turistov zanjo in krepi pripadnost domačinov.

Posledice se izražajo v možnosti za povečanje oz. ponoven obisk destinacije, ki je drugače gost sploh ne bi obiskal, povečevanju publicitete kraja, podaljšani dobi bivanja in v povečanem trošenju. Obenem kakovostno organizirane prireditve s kakovostno vsebino lahko prispevajo $\mathrm{k}$ dvigu ugleda destinacije in postanejo njen promotor. Ekonomske posledice so vidne predvsem v lažjem pridobivanju sponzorjev in donatorjev za prireditev ter v povečanem povpraševanju po storitvah na destinaciji. Še posebej to velja za dlje časa trajajoče in ponavljajoče se prireditve.

Bowdin s soavtorji (2011) in Getz (2008) poudarjajo, da h kakovostni uresničitvi ciljev prireditvenega turizma bistveno prispeva profesionalen pristop, ki pomeni ne samo poznavanje osnov managementa prireditev, ampak tudi prizadevanje za vnašanje verodostojnih vsebin v prireditev. Bowdin s soavtorji (2011) opozarja, da prireditev, ki je pripravljena izključno za obiskovalca, torej prireditvenega turista, in pri tem ne upošteva želja lokalnega prebivalstva, večinoma vodi v izgubo pristnosti in s tem tudi privlačnosti. To posledično pomeni, da je obsojena na neuspeh, saj je za turista kot obiskovalca prireditve najpomembnejše, da na njej doživi pristen utrip kra- 
ja, v katerem začasno prebiva, in ima možnost druženja z domačini.

Opozoriti je treba, da ne smemo enačiti pojmov turistična prireditev in prireditveni turizem. Turistična prireditev je namreč po definiciji ožji pojem, saj gre za turistični produkt in zajema le pripravo ter izvedbo prireditve, medtem ko je prireditveni turizem mnogo širša dejavnost, v kateri je prireditev le njen temelj (Sikošek, 2010). V tuji strokovni literaturi ne zasledimo natančne razlage za turistično prireditev, za katero bi lahko trdili, da je zgolj turistična. Kot sem ugotavljala (Sikošek, 2010), je lahko vzrok za pomanjkanje ustrezne razlage v dveh dejstvih. Najprej v javnosti prireditve, ki se kaže v tem, da se prireditve lahko udeleži vsak, ki je bodisi plačal vstopnico ali pa se ob vhodu prijavil kot gost. To pomeni, da se prireditve v destinaciji lahko udeleži tako domačin kot tudi turist. Na drugi strani pa ne smemo pozabiti osnovnega poslanstva prireditve, ki je bogatitev prostega časa udeležencev oz. animacija gosta in s tem tudi turista, ne glede na to, za kakšno vrsto prireditve gre v vsebinskem smislu. Za prireditve v turističnem kraju velja, da so del turistične ponudbe in spadajo v sekundarno turistično ponudbo oz. med izvedene privlačnosti kraja. Za turistično prireditev torej lahko štejemo vsako prireditev, ki pomeni obogatitev oz. dopolnitev turistične ponudbe na določeni destinaciji in se jo ima možnost udeležiti tudi turist na destinaciji.

Prireditveni turizem kot dejavnost zajema poleg temeljnega produkta - turistične prireditve - tudi celo vrsto drugih aktivnosti, ki prispevajo k uresničitvi prireditve na eni strani in potrošnjo drugih turističnih storitev na drugi. O prireditvenem turizmu se nemalokrat govori tudi kot o prireditveni industriji, to je o razvejani ekonomski dejavnosti, ki zajema zelo širok spekter različnih storitev in produktov. Takšno razumevanje pravzaprav olajšuje predvsem ekonomsko vrednotenje prireditev.

Ko govorimo o prireditvenem turizmu, ne moremo mimo deležnikov prireditev, to je tistih posameznikov in podjetij, ki prispevajo $\mathrm{k}$ uresničitvi prireditve in so s tem tesno povezani z njenim rezultatom. Deležniki prireditev so tiste skupine, ki v prireditvi vidijo predvsem možnost za uresničevanje svojih potreb, želja in tudi koristi. Zavedati se je potrebno, da pri tem obstajajo tudi skupine, ki prireditvi ne dajejo pozitivnega prispevka (npr. udeleženci prireditve, ki na njej razgrajajo). Allen s soavtorji (2011) opredeljuje naslednje skupine deležnikov prireditev: 
- Gostiteljska organizacija, ki je odgovorna za oblikovanje ciljev in upravljanje s prireditvijo.

- Gostiteljska (lokalna) skupnost, ki sodeluje pri oblikovanju konteksta prireditve in se srečuje z učinki prireditev (pozitivnimi in negativnimi). M. Sikošek (2010) izpostavlja, da je lokalna skupnost pomemben subjekt, saj je njeno sodelovanje nujno za uspeh prireditve oz. obratno. Pozitiven odnos lokalne skupnosti do prireditve je pomemben podporni element: izrazi se v odobravanju prireditve in njenih (pogosto) obremenilnih učinkih v skupnosti, v prostovoljskem sodelovanju pri izvedbi ter pozitivnih govoricah o prireditvi.

- Udeleženci prireditve (sodelujoči kot protagonisti prireditve in obiskovalci/gledalci), ki aktivno sodelujejo v prireditvi ali jo podpirajo z obiskom. Gre za subjekte, ki jim je prireditev prvenstveno namenjena, zato je pomembno, da prireditev zadovolji njihove želje in pričakovanja.

- Sodelavci prireditve, ki s svojim delom prispevajo k uresničitvi (izvedbi) prireditve kot take. Kot omenja M. Sikošek (2010), so to lahko redno in pogodbeno zaposleni delavci ali pa prostovoljci. Glede na to, da so prireditve večinoma sezonskega značaja oz. da se ne odvijajo redno, je prisotnost pogodbeno zaposlenih ali prostovoljcev pri pripravi prireditve dokaj pogost pojav.

- Mediji (klasični in digitalni), ki dajejo podporo prireditvam v smislu promocije $\mathrm{v}$ zameno za oglaševalske pravice na prireditvah. M. Sikošek (2010) poudarja, da je osnovno poslanstvo medijev omogočiti prireditvi odmevnost. Čeprav so mediji sprva nastopali le kot "prenašalci« dogodkov na prireditvi, pa se danes ob vse večjem medijskem razvoju celo dogaja, da je prireditev organizirana zaradi zagotavljanja večjega števila gledalcev.

- Sponzorji so posebna skupina deležnikov, ki z materialno ali finančno podporo prispevajo k uresničitvi prireditve. M. Sikošek (2010) opozarja, da imajo sponzorji pri sodelovanju s prireditvijo predvsem poslovni interes, saj v zameno za svoj prispevek pričakujejo medijski prostor oz. prepoznavnost prireditve, ki jo vrednotijo kot poseben marketinški kanal za komuniciranje z zunanjimi javnostmi. Sponzor, imenovan tudi pokrovitelj ali partner prireditve, je pomemben deležnik, zato so prireditve pogosto poimenovane po njem. 
- Javne institucije in organizacije, ki s svojimi storitvami omogočajo izvedbo prireditev, saj le-te skupnosti prinašajo posreden prihodek v obliki pristojbin, taks in davkov ter pomagajo oblikovati imidž kraja ali regije. Prispevek takšnih organizacij se izraža npr. v sodelovanju komunalnega podjetja, upravne enote, policije in drugih javnih služb, brez katerih javne prireditve ne moremo organizirati.

- Profesionalna združenja ali organizacije na področju prireditev, ki dajejo tehnično in moralno podporo organizatorjem prireditev.

Pri organizaciji in izvedbi prireditve imamo v praksi običajno opraviti z več deležniki naenkrat. Ti so pomembni (poslovni) partnerji prireditve, ki jih je treba zato pazljivo izbirati, saj je uspeh prireditve odvisen tudi od njihovega sodelovanja.

\section{Pomen prireditev za turizem in gostiteljsko destinacijo: od vpliva prireditev do njihove zapuščine}

Prireditve so zaradi svoje vloge, ki jo imajo pri razvoju turističnih destinacij in širših regij, pomemben element na različnih področjih človekovega delovanja na nacionalni in globalni ravni. Kot ugotavlja Getz (2008), mnoge države prireditve uporabljajo za doseganje ugleda, poudarjanje svojih dosežkov, podporo v (turistični) prodaji ali za odpiranje svetu. Prireditve so torej lahko pomemben člen v razvoju družbe, v nadaljevanju pa se bomo osredotočili na njihov pomen za turizem in vplive, ki jih s tem prinašajo, ter zapuščino, ki jo ustvarijo za destinacijo.

Že v zgodnejših preučevanjih prireditev in prireditvenega turizma so se avtorji (Delamere idr., 2001; Fredline idr., 2003; Getz, 2008; Deery in Jago, 2010; Bowdin idr., 2011; Bladen idr., 2012; Quinn, 2013) ukvarjali z razčlenjevanjem vpliva prireditev, pri čemer so najpogosteje identificirane štiri temeljne skupine: socio-kulturne, politične, ekonomske in okoljske. Največ pozornosti avtorjev je namenjene ekonomskim in okoljskim vplivom prireditev, kar ne preseneča, saj gre za vplive, ki imajo hitro viden učinek v družbi in gostiteljski destinaciji. Ob obravnavi vplivov prireditev se je potrebno zavedati, da ti niso nujno pozitivni, ampak so lahko tudi negativni, kar je potrebno v gostiteljski destinaciji smiselno uravnavati. V pomoč pri tem je strateški pristop pri načrtovanju prireditev na destinaciji ali regiji. 
Ekonomski vplivi prireditev so najpogosteje odvisni od potrošnje organizatorjev, udeležencev in vlaganj oblasti. Njihova potrošnja ima lahko neposredne, posredne in inducirane učinke. Prvi se kažejo v obliki neposrednega trošenja v zvezi s prireditvijo, kot je nakup vstopnic za prireditev, stroški prevoza ipd., posredni učinki so vidni kot posredno trošenje sredstev od prihodkov prireditve (na primer plačila dobaviteljem za njihove storitve in produkte, ki jih organizator potrebuje za organizacijo in izvedbo prireditve), inducirani pa so daljnosežnejši in se kažejo kot vzpodbujeno trošenje (npr. zaradi plačila za delo na prireditvi zaposleni trošijo za nakup dobrin). Ekonomski vplivi prireditev se kažejo v različnih oblikah in prežemajo različne dele gostiteljske destinacije ali regije. Lahko trdimo, da bolj kot raste obseg prireditev, večji je lahko njihov ekonomski vpliv. Najlaže si predstavljamo pozitivno stran, ko se destinacija zaradi prireditev razvija, veliko je vlaganj v infrastrukturo, vendar pa pri tem ne smemo pozabiti na negativne vplive, ki se kažejo v zadolženosti destinacije ali lokalne skupnosti ali celo v izseljevanju domačinov (Bowdin idr., 2011).

Vplivi prireditev na turizem so podobni ekonomskim, s to razliko, da so usmerjeni posebej v turizem. Njihova pozitivna stran se kaže v obliki promocije destinacije in povečevanju turističnega obiska, podaljšani dobi bivanja, povečevanju prihodkov iz dejavnosti prireditev in turizma na sploh, povečevanju prihodkov z naslova turistične takse in v ustvarjanju novih delovnih mest. Na drugi strani ne moremo prezreti negativnih strani, ki se kažejo v odporu lokalne skupnosti do prireditev in turizma nasploh, izgubi pristnosti prireditve, izgubi ugleda destinacije, prekomernem izkoriščanju virov (kulturnih, naravnih), možnosti povečevanja cen na destinaciji zaradi povečanega povpraševanja in v oportunitetnih stroških (izguba prihodka, ki bi lahko nastal iz druge aktivnosti, če prireditve ne bi organizirali).

Z ekonomskimi so močno povezani družbeni vplivi, zato jih nekateri avtorji obravnavajo skupaj (Bowdin idr., 2011). Ti se kažejo zlasti $\mathrm{v}$ dvigu zavesti in ponosa lokalne skupnosti, oblikovanju pozitivnega imidža destinacije, povečevanju števila delovnih mest, v razvoju infrastrukture in dobrin, ki izboljšujejo vsakdanje življenje domačinov (Deccio in Baloglu, 2002). Negativni družbeni vplivi se kažejo npr. v zmanjšanju varnosti na destinaciji, oteženem dostopu do zdravstvenih storitev, izseljevanju domačinov, motnjah v vsakdanjem življenju lokalne skupnosti. V ospredju razprav o razvoju turizma, tu- 
di prireditvenega, so razprave o trajnostni usmeritvi prireditev, saj imajo te prav poseben vpliv na svoje naravno in družbeno okolje. Še posebej v tem primeru prednjači zavedanje o negativnih vplivih prireditev na okolje zaradi njihove narave - združevanja večjih skupin ljudi. Negativni vplivi se kažejo npr. v poškodovanju prizorišča prireditve, večji količini odpadkov, onesnaženju s hrupom in svetlobnimi učinki, preseganju nosilne zmogljivosti destinacije. Na drugi strani pa so pozitivni okoljski vplivi vidni v povečani skrbi za okolje, razvoju komunalnih rešitev, prizadevanjih za zaščito okolja (Delamere idr., 2001; Fredline idr., 2003; Deery in Jago, 2010).

Pomembni so tudi politični vplivi prireditev, ki se kažejo predvsem v dvigu političnega ugleda države ali regije, povezovanju med njimi, promociji investicijskih možnosti v državo, na drugi strani pa se lahko pojavi možnost neuspeha, neprimerne razporeditve razpoložljivih sredstev ali propagiranje političnih idej in ideologij (Bowdin idr., 2011).

Ob vplivih, ki jih imajo prireditve na svoje okolje, ne moremo mimo koncepta zapuščine prireditev, ki jo te ustvarijo v gostiteljski destinaciji. Pomembna razlika v razumevanju vplivov in zapuščine prireditev je v tem, da so vplivi kratkotrajnejši, zapuščina prireditev pa je dolgotrajne narave (Thomson idr., 2013). Koncept zapuščine prireditve je najpogosteje povezan s športnimi prireditvami, še posebej megaprireditvami, kot so olimpijske igre. Razumemo jo kot tisto, kar po prireditvi nepreklicno ostane gostiteljski skupnosti oz. destinaciji v nadaljnjo uporabo za daljši čas. Kot primer lahko navedemo za potrebe prireditve zgrajeno športno, nastanitveno, transportno infrastrukturo (parki, poti, ceste, športne dvorane, hoteli), ki po prireditvi ostane za nadaljnjo uporabo in trženje gostiteljski destinaciji, ki z njo lahko upravlja po lastni presoji in brez obveznosti do organizatorja. A. Thomson idr. (2013) opozarjajo, da ima zapuščina prireditve tudi svojo negativno stran, predvsem takrat, ko je gostiteljska destinacija ne nameni uporabi, z njo pa ima zato predvsem visoke stroške in okrnjen ugled.

Prav zaradi dejstva, da imajo prireditve določen vpliv na svoje okolje v najširšem pomenu te besede, hkrati pa ustvarjajo nepozabna doživetja za deležnike prireditve, še posebej za udeležence, ki so jim prvenstveno namenjene, je potrebno na nadaljnji razvoj prireditev in prireditvenega turizma gledati predvsem strateško. To pomeni poglobljen razmislek in v prihodnost usmerjeno odločitev o tem, 
kaj prireditev je, komu je namenjena ter kaj lahko prinese in ponudi udeležencem, skupnosti in gostiteljski destinaciji; predvsem pa razmislek o tem, da so prireditve osnovna celica prireditvenega turizma, ki pomagajo zadovoljiti motive številnih prireditvenih turistov in oblikujejo strateški razvoj destinacij.

\section{Literatura}

Allen, J., O’Toole, W., Harris, R., in McDonnell, I. (2011). Festival and event management (5. izd.). Wiley.

Bladen, C., Kennell, J., Abson, E., in Wilde, N. (2012). Events management: An introduction. Routledge.

Bowdin, G., Allen, J., O’Toole, W., Harris, R., in McDonnell, I. (2011). Events management (3. izd.). Butterworth-Heinemann.

Connell, J., Page, S. J., in Meyer, D. (2015). Visitor attractions and events: Responding to seasonality. Tourism Management, 46, 283-298.

Deccio, C., in Baloglu, S. (2002). Non-host community resident reactions to the 2002 winter olympics: The spillover impacts. Journal of Travel Research, 41(1), 46-56.

Deery, M., in Jago, L. (2010). Social impacts of events and the role of antisocial behaviour. International Journal of Event and Festival Management, 1(1), 8-28.

Delamere, T. A., Wankel, L. M., in Hinch, T. (2001). Development of a scale to measure resident attitudes toward the social impacts of community festivals, part 2: Verification of the scale. Event Management, $7(1), 25-38$.

Ferdinand, N., in Shaw, S. J. (2012). Events in our changing world. V N. Ferdinand in P. J. Kitchin (ur.), Events management: An international approach (str. 5-22). Sage.

Fredline, L., Jago, L., in Deery, M. (2003). The development of a generic scale to measure the social impacts of events. Event Management, $8(1), 23-37$.

Getz, D. (1989). Special events: Defining the product. Tourism Management, 10(2), 135-137.

Getz, D. (1997). Event management and event tourism. Cognizant.

Getz, D. (2005). Event management and event tourism (2. izd.). Cognizant.

Getz, D. (2007). Event studies: Theory, research and policy for planned events. Butterworth-Heinemann.

Getz, D. (2008). Event tourism: Definition, evolution and research. Tourism Management, 29(3), 403-428.

Getz, D., in Page, S. J. (2016). Progress and prospects for event tourism research. Tourism Management, 52, 593-631. 
Hall, C. M. (1992). Hallmark tourist events: Impacts, management and planning. Belhaven Press.

Jago, L. K., in Shaw, R. N. (1998). Special events: A conceptual and definitional framework. Festival Management in Event Tourism, 5(1), 21-32.

Lai, K. (2015). Destination images penetrated by mega-events: A behaviorist study of the 2008 Beijing Olympics. Asia Pacific Journal of Tourism Research, 20(4), 378-398.

Lucia, M. D. (2013). Economic performance measurement systems for event planning and investment decision making. Tourism Management, 34, 91-100.

Mair, J., in Whitford M. (2013). An exploration of events research: Event topics, themes and emerging trends. International Journal of Event and Festival Management, 4(1), 6-30.

Müller, M. (2015). What makes an event a mega-event? Definitions and sizes. Leisure studies, 34(6), 627-642.

Quinn, B. (2013). Key concepts in event management. Sage.

Raj, R., Walters, P., in Rashid, T. (2013). Events managements principle in practice (2. izd.). Sage.

Richards, G., de Brito, P. M., in Wilks, L. (2013). Exploring the social impacts of events. Routledge.

Ritchie, J. R. B. (1984). Assessing the impact of hallmark events: Conceptual and research issues. Journal of Travel Research, 23(1), 2-11.

Shone, A., in Parry, B. (2004). Successful event management: A practical handbook (2. izd.). Thomson Learning.

Sikošek, M. (2010). Management prireditev: organizacija študentskih prireditev. Fakulteta za management.

Sikošek, M. (2017). Kongresna dejavnost: vidiki privlačnosti destinacije. Založba Univerze na Primorskem.

Slovar slovenskega knjižnega jezika. (2014). Založba zRC. http://www fran.si

Slovenian Tourist Board. (2019). Slovenia: My way of diverse experiences [brošura]. https://www.slovenia.info/uploads/publikacije/tam2019/ travel-agents-manual-2019-en.pdf

Thomson, A., Schlenker, K., in Schulenkorf, N. (2013). Conceptualizing sport event legacy. Event Management, 17(2), 111-122.

Zakon o javnih zbiranjih (ZJZ-U PB5). (2011). Uradni list Republike Slovenije, (64). https://www.uradni-list.si/1/objava.jsp?sop=2011-01-2970 